\title{
THE APPEARANCE OF GERMAN DIRECT INVESTMENT IN CONNECTION WITH THE PRESENCE OF GERMAN MINORITY IN HUNGARIAN SMALL TOWNS
}

\author{
Klára J. STEFÁN ${ }^{\mathrm{a}}$, Levente B. ALPEK ${ }^{\mathrm{b}}$, Viola KARSAI ${ }^{\mathrm{a}}$ \\ ${ }^{a}$ Doctoral School of Earth Sciences of the University of Pécs, H-7624 Pécs, Ifjúság Str. 6. \\ stefan.klari@gmail.com; vivi2799@gmail.com \\ ${ }^{\mathrm{b}}$ Faculty of Sciences, Institute of Geography and Earth Sciences, H-7624 Pécs, Ifjúság Str. 6. \\ alpeklevente@gmail.com
}

Cite this article: Stefán, K.J., Alpek, L.B., Karsai, V. (2019). The Appearance of German Direct Investment in Connection with the Presence of German Minority in Hungarian Small Towns. Deturope, 11(3), 250-263.

\begin{abstract}
In the decades, following the political transition more and more researchers started to study the Hungarian small towns because of the increasing number of settlements belonging to this category and their dominant role in the urban network. The literature studying the opportunities in foreign direct investment do not deal or only negligently deal with the effects of social and economic processes on the life of small towns. After reviewing the different approaches of location theories, we can get an overall picture in the relation of settlements and direct investment. This gives answers to the specific forms of direct investment flow and settling in East-Central Europe as well. Besides this, the presence of German minority as the indicator of the settling of direct investment is a missing segment of literature. This study presents the partial results of our research, which aims to complement this missing literature and studies the presence of German direct investment in the small towns of Hungarian settlement structure. It analyses the historical GermanHungarian relations, through which it describes the role of German minority in the economy and the settling of direct investments. The research studies the sectoral structure, the special pattern and it differentiates the importance of German direct investment with the help of data from the available databases (DUIHK ${ }^{25}$ member list and creditreform.hu - HVG TOP 500 enterprises), structured in-depth interviews (leaders of settlements, directors of companies and civilian organizations related to German minority) and regression analysis. The impact of foreign direct investment on social life, its role in living a life of a small town dweller and in obtaining the title of township are introduced by two short case studies. One of the settlements is Bonyhád, having one of the largest German minority and the other is Újhartyán, belonging to the outer ring of agglomeration of Budapest. Besides their favourable potentials the presence of German minority plays a crucial role in forming the economic and social life of these settlements. Our study shows the presence of German direct investment adjusting to the spatial structure of Hungarian economy and its sectoral differentiation is specific to a given region.
\end{abstract}

Key words: small town, German minority, applied methodology

\section{INTRODUCTION}

The 1990s brought about changes in the expansion of German enterprises regarding their geographical orientation. By the opening of the markets of former socialist countries the German enterprises found new markets, thus by the 1990s the more developed countries of the

\footnotetext{
${ }^{25}$ Deutsch-Ungarische Industrie- und Handelskammer
} 
region (Czech Republic, Hungary, Poland) were among the most important target areas. In that time, in East-Central Europe the German direct investment often resulted in the relocalization of production capacity. These were mainly market-based, though, at the same time they were cost-oriented as well. The relocalization of production and supply capacities in the first half of the 2000s become a more and more important element in the international division of labour. In Hungary, relocalization mainly affected the electronics industry and the car manufacturing (Hunya \& Sass, 2006). After the turn of the millennium the second wave of ,eastern expansion” has begun. The attraction of foreign direct investment has a great importance in the economic development of both the developed and developing countries. Outsourcing in developed countries like Hungary had placed industrial activity which played a significant role in the reindustrialization of Hungary (Barta, Czirfusz, \& Kukely 2008). From the installation factors, many soft elements come to the fore during reindustrialization. The widening of supplier network can be observed in relation with multinational corporations, which are settling down in the lower levels of settlement hierarchy as well.

Present study analyses the effects of German minority on the economic life of the given settlement based on local advantages formulated in the location theory of Porter (1996). It is rooted in the German-Hungarian historical relations, which are undoubtable, though their strength and judgement are altering. Our aim was to find out whether the presence of German minority acts as an installation factor or not. Does the German direct investment have a dominant economic role in small towns? Is a settlement with less than 30,000 inhabitants suited for a multinational enterprise? Do we find any small town in Hungary having large employers with German interests and does the presence of German minority have a dominant role in its settling? Regarding the sectoral division in small towns, either the shared service functions or the economic life is centred around the trio of production-storage-commerce. The research also includes the questions regarding corporate social responsibility (sponsoring events, supporting institutions, development of playgrounds or infrastructure, eco-conscious attitude), which we identify as the role of direct investment in the life of settlements and introduce through case studies.

\section{INFORMATION AND METHODOLOGICAL BACKGROUND OF THE RESEARCH}

The development of the database for the research is the result of a multistage process. First, the 2017 data of the German-Hungarian Chamber of Commerce and Industry was examined regarding the number of its members. Afterwards, the seats and sites of business of the given 
companies were searched and finally those with German interests were sorted out. Besides this, the member list was completed with the German enterprises having the highest revenue on the bases of data from the annually published Creditreform (HVG TOP 500). The process was similar to the former one, thus we searched the site of businesses and then those with German interest were sorted out. The settlements were classified into different levels of town collective according to the number of inhabitants assigned to the site of business. The definition of small town is not coherent even in the literature as well, thus our very first task was to define it. We had chosen the criteria of less than 30,000 inhabitants and extended it to those settlements without the status of township, which are affected by the enterprises. Thus, involving altogether 74 settlements into the research. Újhartyán, as the 75th element, having German relations was also included in our table as a counter example, case study along with Bonyhád. Despite its German past only one German enterprise is working in Bonyhád. Based on the previously agreed research principals the first column of the data table contains the list of the small towns having less than 30,000 inhabitants. After that the rate of German minority was assigned to these settlements from the gazetteer of KSH (Central Statistical Office) 2018. The range of activities of enterprises, the income from business taxes, the year of getting the status of town and the year of foundation of the first firm with German interest were also recorded. We also got the data about the changes in the number of employees through the databases homepages of Opten and Céginformáció. To complete the latter one, we also collected the educational data and studied its effect in relation with the firms. Besides these data we also studied the regional aspects, thus the vicinity of highways. We explored whether a "medium" town with a population of more than 30,000 inhabitants can be found within a radius of $20 \mathrm{~km}$ of a given settlement and weather this has any effect on the enterprises with German interests. In connection with this, we tried to explore the legal status and its role based on the examined sample. This data template was analysed with regression analysis and studied weather the presence of Germans makes the appearance of German companies more likely. The table of data was analysed using regression analysis and entering process to reveal whether there is a correlation or not between the German presence and the settling of German enterprises. Only the revenues have a significant effect on the dependent variable, but there was a conceptual mistake as the variables do not have a direct effect on employment, thus they do not influence the companies in choosing their site of business. It is interesting to study how the settling of the first company with German interest affects the companies already settled in the towns with German capital. It cannot be ignored when examining the relationships, that certain historical and economic turning points (transition, EU accession and the economic crisis of 2008) 
influence the settling and intensity of German direct investment. We tried to complete the results of the mentioned methods with interviews, which have resulted in two short case studies introduced in this article. One is about a traditional small town with German minority, traditional industrial structure and unique product supply and a new small town with dominant German minority and specialized product structure. Unfortunately, we do not have the opportunity to conduct an exhaustive survey due to the lack of data service. Thus, our database was completed with the data regarding the number of employees, net revenue and the amount of the payed business tax.

\section{German direct investment in Hungary}

The background of the research has several segments. Germany as a significant product and capital exporter country of world economy - the 3rd in the world rank after the USA and China, with a share of $7.9 \%$ (MNB, 2018) - is a special segment in the economic life of Hungary. The export oriented economic development model, following the transition, was based on foreign direct investment (Juhász, 2016), in which Germany - as the number one investor of Hungary - has a key role (Wölfer, 2018). Several studies, analysing the export of foreign direct investment and the settling of German direct investment itself were published in the last decade (Körösi, 2009, Vápár, 2013, Juhász, 2016,). Foreign direct investment strategies and patterns have been investigated in details both in the East-Central European and post-socialist context (Estrin, Richet, \& Brada, 2000; Pavlinek, 2004; Popescu, 2014; Jasiniak \& Pastusiak, 2014; Hlavacek \& Bal-Domaska 2016). The main findings of the dominantly economic analyses among others that a correlation - in a varying scale - can be found between the value of FDI and economic development, growth. The question of simple correlation was also completed by the issue of spatial pattern and penetration models, while works on the German FDI's impact were mainly published in the new millennium. However, no comprehensive research has been done regarding the settling of German direct investment in small towns and its cause and effects. The reason behind this study is the outstanding role of German direct investment in the economic life, which results in a unilateral economic dependence in Hungary. The relocalization of production capacities from the 2000s affected mainly the electronics industry and car manufacturing (Hunya \& Sass 2006), while outsourcing had a role in the reindustrialization of the country (Barta et al., 2008). Considering its regional distribution, we can conclude that about one quarter of German direct investment in East-Central-Europe was realised in Hungary, while regarding its sectoral distribution in the Visegrád Group countries, 
we can say that one quarter was invested in industry and two-thirds in the tertiary sector (DUIHK, 2017). The question of business site is also important. The business site model of Lösch (1940) should be approached from the site of supply and demand. The locally available resources and the aspect of agglomeration, as a link between the local and global levels, come to the forefront in the location theory of Porter (1996). The installation decisions interpreted in two different levels prioritise the possibility of an effective management of resources available at a micro-level (physical geographical environment, infrastructure, availability, relative position, amount of employees, qualification, local taxes and subsidies, image of site, economic environment, the already presenting enterprises, vicinity of higher educational and research and development institutions). Concerning these factors, the regression analysis is worth applying to determine the strength of correlation between the factors. There is an interesting dichotomy in the definition of small towns as economic sites of business. Two case studies introduce those parts of the settlement system, which once were small towns arranged around the former industrial activities and after the disintegration of industry tried to find their own characteristic way. At the same time and regarding the territorial characteristics an interesting pattern can be seen as nods and local cooperation can be observed.

\section{Small town as an economic site of business}

It has a basic importance to define, which small town concept to be accepted from the so many concepts made by several researchers based on settlement size (Beluszky, 1999, Tóth, 1996, Köszegfalvi, 2004, Pirisi, 2008, Dövényi, 2009). We had chosen the 30,000 inhabitants as a value formulated by Gábor Pirisi, as it proved to be appropriate for the analysis of the characteristics of the present-day Hungarian settlement network and sizes. Pirisi studied the functional development types of small towns about the fact that these are the centres of local areas. Their importance was proved by the growing number of their functions in the middle of the 2000s - before the crisis of 2008-2009 (Pap, 2004, Pirisi, \& Trócsányi, 2006). The last 30 years show that the present image of the urban network is defined by formal urbanization (Konecka-Szydlowska, Trócsányi, A., \& Pirisi, 2018), which means more towns were born through an administrative way (reclassification), than what would correspond to the general expectations of a town. Out of the 346 towns, 182 had got its rank after the political transition, thus their number doubled, but at the same time this meant that most of them could not meet the basic functions of a town. They are rather the emitters of employees than the attractors, though it is a criterion of towns in the regulation of town declarations. So, it is an interesting question how a small town can attract a bigger firm (of course together with many smaller ones) 
and to concentrate the labour force and how it affects the settlement itself and its agglomeration. All these can be compared with the possibility of the attracting force of inhabitants with German past and what kind of relations can be observed. The chosen size category is confirmed by the fact that with the town rank the number of inhabitants constantly decreased and finally went under 5,000, thus the share of small towns within the town network has increased. The question is, how they can increase their importance within the studied economy. This, through the already mentioned historical and traditional German-Hungarian relationships, should be studied considering the intensive German influence. Besides this, following the dissolution of the Soviet Union and the end of commercial relationships, the Hungarian market and enterprises had to change and meet the requirements of the West. Earlier there can be found two bigger categories of towns: those which were awarded the town rank before 1970, fulfil the requirements of functional aspects, have agglomeration and within it an employment agglomeration and have a higher number of inhabitants. The socialist industrial development added several towns to the urban network, which were the results of a forced (industrial) urban development. In these towns, there was a need for a structural change after the political transition. Among them, we can find some of those studied towns, which have less than 30,000 inhabitants. Several authors dealt with the introduction of a small town as a site for business. In the case of the former industrial towns, which had lost their functions we can find many comparative articles, based on the former and present installation factors (Pirisi \& Sókuti, 2013, Molnár \& Lengyel, 2015, Lovász \& Pirisi, 2017). It is an outstandingly important field of questions as the Hungarian industry is integrated in the global production network and the opportunity of moving forward lies in turning towards sectors with higher added-value (Lux, 2013). The effect of reindustrialization on settlements in a lower hierarchy level is another interesting question. How the appearance of shared service functions has changed the priority order of the settling down of sectors related to the traditional branches of industry with higher added-value and expertise? In today's globalised world and in a transitional country like Hungary, the accessibility of settlements as business sites is of basic importance in order to place the elements of settlement network into a hierarchy. The western borderland of Hungary has been in a more advantageous situation after 1990, but with the expansion of its expressways and highways many settlements gained also favourable positions, more advantageous than it would be on the bases of their geographical position, though many were excluded as well. Small settlements, which otherwise would belong to the shrinking majority (Pirisi, \& Trócsányi, 2015), appeared on the map of enterprises searching for business sites. 


\section{The effects of German minority on investments}

Our research done by regression analysis and the summary of the available statistical database has provided an interesting outcome. The number of employees and businesses of companies with German interest had an outstanding role in both types of research methods. With the help of the former one we can define the range of dimensions, while the latter one meant the dependent variable in the regression analysis.

\section{Geographical location of the German minority in Hungary}

After selecting the companies with German interest from the database, we have gained an easily interpretable spatial image, on which the bigger cities and the county seats outstand and besides the territories with German presence the settlements of the Great Hungarian Plain and Northern Hungary are also represented as the elements of dependent economy. The capital and its agglomeration are over-represented in contrast with the other studied settlements, thanks to their central situation and their installation factors.

The inflow of German direct investment to Hungary had more waves and with different intensity. Its first wave arrived before the political transition and was incorporated into the traditional economic sectors in the form of wage work. The period from the first half of the 1990s was the period of privatization, the era of brown- and greenfield projects, when the German direct investment as a solution had arrived. In this period the informal relationships, the German language knowledge, and the competence of the employees were important, it meant a bases for working morale. The period of recovery following the economic crisis meant the third big change, the rapid inflow and intensive presence of German direct investment can be observed during reindustrialization. It gained significant role both in the dependent economy and in the shared service function thanks to its supplier network. The higher added-value segments came to the forefront (specialized expertise, high level informatics knowledge) and the foreign direct investment is internationalized (the business language is English, the German language knowledge does not mean any advantage).

As we take a closer look at small towns, the traditionally German inhabited areas in Transdanubia stand out, just like those near the western borderline. Many small towns from the agglomeration area of the capital are presented, from which those who gained the town rank in the middle of the 2000s have an advantage as not only the presence of minority has a positive effect on the settling of direct investment, but also their advantageous position. Considering the historical background, belonging to a nationality is quite a specific question for the minorities living in Hungary, thus these statistical data should be handled carefully. According to the 2018 
data of the gazetteer of KSH (Central Statistical Office) the settlements, where the ratio of minority in relation to the population ranges between $0.3 \%$ and $0.5 \%$, are sparsely located within the country, mostly in Transdanubia, but are concentrated in the traditionally German inhabited areas. They appear isolated in the Great Hungarian Plain as a result of the political interventions. The number of settlements with 5\%-25\% of German minority of inhabitants with German ancestors is lower but their location is concentrated. They are the so called Schwäbische Türkei, located in Tolna and Baranya counties (Bonyhád, Bóly), plus the traditionally German settlements around the capital (Piliscsaba, Budaörs) and one town (Herend) from Veszprém county. From the studied database only two settlements (Hajós and Újhartyán - both of them are located at the Great Hungarian Plain) with less than 30,000 inhabitants have higher than $40 \%$ of German minority.

\section{German interests and their appearance in the Hungarian network of small towns}

The number of employees, the revenues or the amount of corporate or business taxes are the indicators of the size of companies. On the basis of the former one, four categories can be separated. The micro-enterprises (having less than 10 employees) are dominant around Budapest. The small enterprises (10 to 50 employees) with their commercial and logistic role are mainly present in the agglomeration of Budapest, though they continue the traditional productive activities in rural small towns (Bonyhád, Bóly, Herend). The medium enterprises (50 to 250 employees), which are the bases of the well-known multinational companies (Koch, Zentis, Haribo, Sio-Eckes) in Hungary, had chosen their sites of business in small towns and most of them are engaged in food industry. According to the available data the large enterprises are quite prominent among the firms with German interest. The smaller ones are mainly attached to traditional sectors (machine tool manufacturing industry), along with which the highly specialized, higher added value activities gained ground (lenses, nanoperm, innovative plugging). Their sites are in the settlements which have got the town rank before 2000. The medium sized large enterprises (500-999 employees) are strengthening the economy of the newer small towns. As suppliers, their sectoral structure is attached to car manufacturing, the leading sector in Hungary (engineering, electronics, ventilator, engine). The sectoral spectrum of large enterprises with more than 1,000 employees is diverse regarding the industry (tires, electronic moving parts, industrial robots), the retail market and logistics. Considering their spatial situation, the agglomeration around the capital is outstanding in the case of retail trade, while in the case of secondary sectors the settlements with industrial past are also represented (Sátoraljaújhely). 
Figure 1 The German enterprises in the small towns

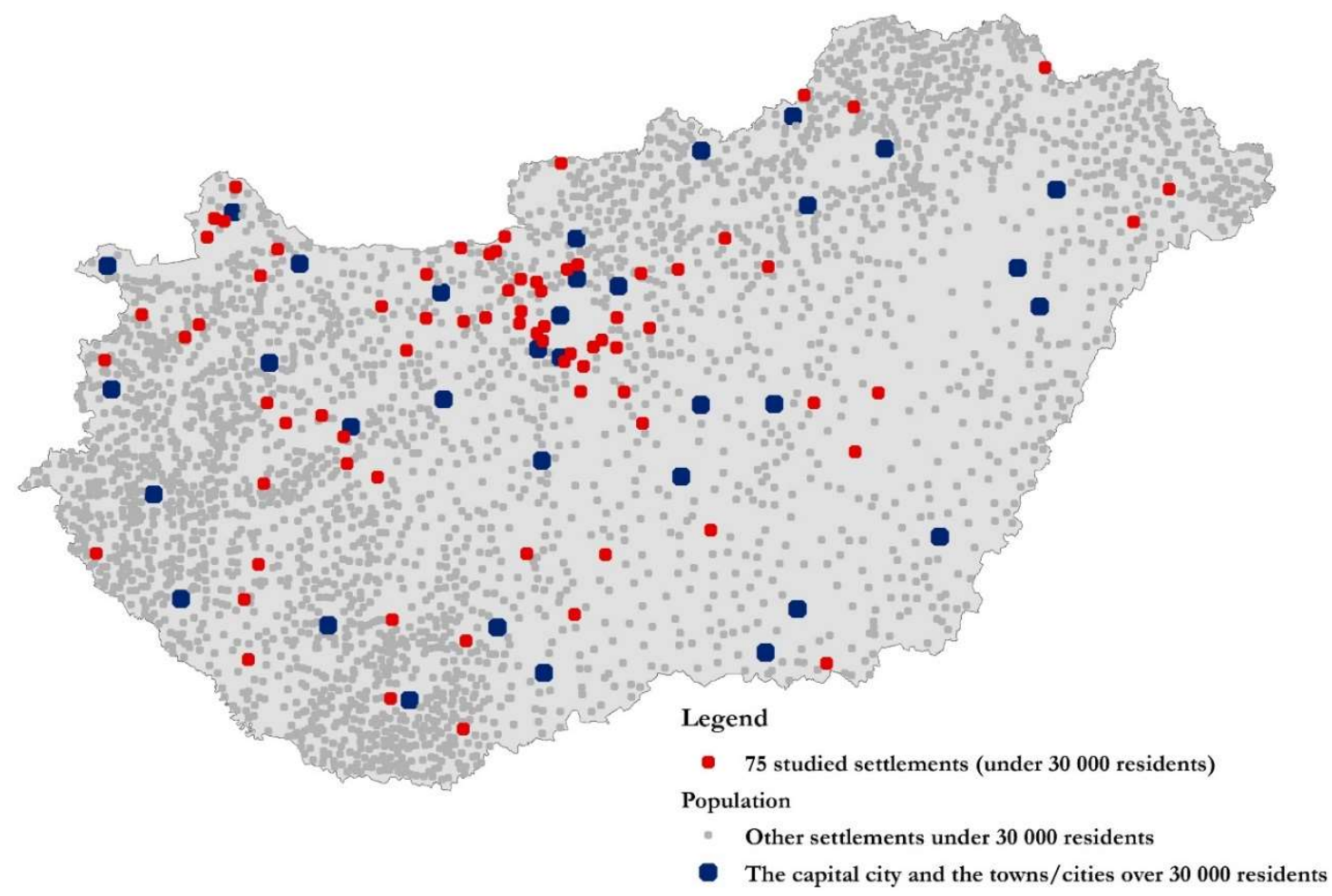

Source: Ed.: Karsai, V. based on available database (Creditreform.hu, DUIHK member directory)

\section{RESULTS}

\section{Results of the regression analysis}

With the regression analysis we aimed to show if there is any correlation between the presence of German population and the number of firms with German interest in a given settlement. A simple part of this is the so-called correlation coefficient, which we also studied, and it revealed that there is a correlation between the number of firms with German interest and the employees.

In the present analysis, with the use of linear regression, we had studied how the different factors - relevant according to the literature and the results of primer research - influence the number of German enterprises in the given settlements ${ }^{26}$. Besides theoretical considerations, the availability of data as well as the indicators to be quantifiable for most of the settlements had a key role in selecting the range of independent variables. In order to avoid multicollinearity we only used those variables in the model, which correlation did not exceed 0.7 . Thus, the independent variables included the ratio of German population, the presence of German enterprises (the duration of operation of the currently existing German firms in years), number

\footnotetext{
${ }^{26}$ Budapest was excluded from the present study.
} 
of towns with more than 30,000 inhabitants within a radius of 40 kilometres around the given settlement, the amount of business tax, the number of qualified employees and the length of the shortest route in kilometres until a highway junction. We had used the most recent data. The model proved to be relevant on the basis of $\mathrm{F}^{-\operatorname{test}^{27}}{ }^{27}$ the value of the coefficient of multiple determination was 0.276 , while the values of adjusted R-squared was 0.211 . The presence of German enterprises, the number of towns with more than 30,000 inhabitants within a radius of 40 kilometres and the number of qualified employees had a statistical significance at 0.05. Among these variables the presence of German enterprises and the number of qualified workforce proved to be stronger on the basis of standardized beta coefficients (Tab 1).

Table 1 The standardized beta coefficients, significance and T-probe of values included in the model

\begin{tabular}{lccc}
\hline Name of variable & $\begin{array}{c}\text { Standardized } \\
\text { coefficients }\end{array}$ & $\begin{array}{c}\text { betaValue of T- } \\
\text { probe }\end{array}$ & Significance \\
\hline Constants & - &, 064 &, 949 \\
$\begin{array}{l}\text { Ratio of German minority } \\
\text { Presence of German enterprises }\end{array}$ &, 029 &, 266 &, 791 \\
$\begin{array}{l}\text { Number of towns with more than 30,000 inhabitants } \\
\text { within a radius of } 40 \text { kilometres }\end{array}$ &, 236 & 3,129 &, 003 \\
$\begin{array}{l}\text { Amount of business tax } \\
\text { Number of qualified employees }\end{array}$ &,- 092 & 2,052 &, 044 \\
$\begin{array}{l}\text { Length of the shortest route in kilometres until a } \\
\text { highway junction }\end{array}$ &,- 067 &,- 773 &, 442 \\
\end{tabular}

Source: Ed.: Alpek, L. 2019.

The ratio of German minority as the soft-element in our assumption does not proved to be significant. The reasons behind are varied as the waves of German direct investments has had different characteristics since the period following the economic crisis. With the emergence of internationalization and shared services the significance of German minority does not play a crucial role in choosing the site of business.

\section{Case studies of small towns: Bonyhád and Újhartyán}

This has been proven by our two case studies as well, which were prepared on the bases of results from online questionnaires and guided interviews. Bonyhád is an "old" small town on

\footnotetext{
${ }^{27}$ Value of F-probe is 4.258, significant at 0.01 statistical significance, sig. $=0.001$.
} 
the neighbourhood of Tolna and Baranya counties, which gained its town rank in 1977. It is one of the bases of German minority, the ratio of German nationality in relation to the population is $15 \%$ (KSH 2018). 10 out of 14 sent questionnaires were filled out. Within the town, four companies with German interest were operating. During the interviews we had questions regarding their reasons of site selection (J. Stefán, K. 2018) and the importance of German minority in the life of the settlement and the company. The German enterprises in small towns modernized traditional sectors and become the suppliers of leading sectors (mainly car manufacturing), and the part of dependent economy. Almost all of them are medium sized enterprises, which have settled in Bonyhád at the end of the 1990s and the beginning of the 2000s. During this time the number of expertise, the German language knowledge and the informal relationships were installation factors. In the case of more than half of the present companies' family relations and friendships helped the decision making. The taking of German nationality is exemplary in the town as the public spaces, the playground, the beach had all been renewed with the help of German capital and the support of events is continuous. Újhartyán acts as a counter example. It got the town rank in 2013, and is located in the southern part of Pest county, at the outskirts of the capital's agglomeration. The ratio of German population is $40 \%$ (KSH, 2018), though the first German investor only appeared in 2019, while other foreign investors (Japanese, American, Swiss) have been present since the establishment of the industrial park. The enterprises questioned (22 questionnaires, eight online questionnaires and three interviews) all agreed that the business site provided by the industrial park is an installation factor due to its accessibility (next to the M5 highway), the number of available workforce and the affordable tax rates. The ratio of employees with tertiary education is around $10 \%$, but high-level English knowledge is a must. Only the small and medium size enterprises practice the corporate social responsibility (by sponsoring events), the multinational enterprises do not take part in it, though they are open to cooperate.

\section{CONCLUSIONS}

Though, the questionnaires and the interviews proved our assumption - the presence of German minority is an advantage during the selection of business sites - to be honest, the pure statistical analysis with the regression analysis disproved it. Therefore, it is only partially verified. The reasons include the historical background, the subjectivity of taking on nationality and the role of milestones in Hungarian economic life. There is a dichotomy when it comes to the effects of German minority on the settling of foreign direct investment as the relation was disproved by statistics. However, the interviews revealed that after the transition and privatisation and with the informal relations becoming formal the German direct investment helped the economic 
restoration of the settlements with significant German minority. The activities related to the traditional sectors are going to live on and as the suppliers of main economic sectors they contribute to the productions of higher value-added products. The foreign enterprises moving to settlements assigned newly with the rank of a town choose their business sites on the bases of existent adequate infrastructure, existent human resources and the number of already settled companies. These are the priority factors; all the other factors are tasks to solve. The map, drawn based on the available database, highlights the settlements around the capital, mainly because of their infrastructure. Though, the economic activity revived with the help of German capital features several small towns on the map, which emerge along the western boundaries, in Tolna and Baranya counties, near the eastern and northeastern boundaries and in the middle of the Great Hungarian Plain. As a result of the development of supplier network and the strong influence of dependent economy, mainly the settlements, which have been awarded by the town rank in the near past (economic crisis of the late 2000s), in the agglomeration of Budapest are the bases. These settlements have investors mainly in the fields of logistics, services and transportation. There is a special relationship, the small town with multinational company, which is worth mentioning. It results in a strong unilateral dependence and the profile includes a very specific production. The settlements listed in our database and the accompanying companies with German interest have a completely different motivation. On the one hand tradition - both in the cases of economic activity and the presence of direct investment - and the skilled human capital, which is a good basis for an enterprise stands, while on the other hand the expertise representing higher added-value and the infrastructure appears.

\section{REFERENCES}

Barta, G. (2005). The Role of Foreign Direct Investment in the Spatial Restructuring of Hungarian Industry In: Hungarian Spaces and Places, MTA RKK, Pécs, 143-161.

Barta, G., Czirfusz, M., \& Kukely, G. (2008). Újraiparosodás a nagyvilágon és Magyarországon. Tér és Társadalom. 4, 1-20.

Beluszky, P. (1999). Magyarország településföldrajza. Általános rész. - Dialóg Campus Kiadó, Budapest-Pécs, $584 \mathrm{p}$.

Dövényi, Z. (2009). "Város az, ami magát annak nevezi": tünődések Tóth József tanulmánya kapcsán. Területi Statisztika 12,1, 3-7.

Estrin, S., Richet, X., \& Brada, J.C. (2000). Foreign direct Investment in Central Eastern Europe - Case Studies of Firm in Transitition, M.E. Sharpe.

Gál, Z. \& Sass, M. (2009). Emerging new locations of business services: offshorting in Central and Eastern Europe In: Regions 1, 18-22.

Hlavacek, P., \& Bal-Domanska, B. (2016). Impact of Foreign Direct Investment on Economic Growth in Central European Countries. Engineering Economics, 27(3), s. 294-303.

Horecki, R. (2014). A kisvárosok ipari átalakulása a XX. században, Köztes-Európa, VI, 1,135143. 
Hunya, G., \& Sass, M. (2006). Nyer-e Magyarország a termelés-kihelyezéssel? Külgazdaság, $2,33-54$.

Jasiniak, M., \& Pastusiak, R. (2014). The profitabilty of foreign and domestic enterprises in Poland. Business and Economic Horizons, 10, 2, pp 86-93.

Karsai, V., \& Sass Trócsányi, A. (2018). Statisztikailag város - Városiasság a várossá nyilvánítások tükrében. In Fazekas, I. - Kiss, E. - Lázár, I. (Eds.). Földrajzi tanulmányok 2018, MTA DTB Földtudományi Szakbizottság, Debrecen, 2018, 279-284, from http://old.geo.science.unideb.hu/foldrajzkonf2018/docs/MFK2018Deb.pdf

Köszegfalvi, G. (2004). Magyarország településrendszere. Történelmi vázlat településrendszerünkröl. - Alexandra Kiadó, Pécs, 158 p.

KSH (2017). Magyarország és Németország közötti kapcsolatok, Statisztikai Tükör, 1, 9 p.

Körösi, I. (2009). A magyar-német gazdasági kapcsolatok fejlődésének húsz éve (1989-2009) a tíz új EU-tagországgal összehasonlítva, Külügyi Szemle, 3, 3-43.

Lovász, V., \& Pirisi, G. (2017). Esztergom - egy sikertelen kisváros? Területfejlesztés és Innováció, 11(2), 17-28.

Lösch, A. (1940). 1940. Die räumliche Ordnung der Wirtschaft. Jena: G. Fischer. English translation (of the 2nd rev. ed.): The Economics of Location. New Haven: Yale University Press, 1954.

Lux, G. (2013). Az ipari versenyképességi tényezőinek átalakulása a közép-európai gazdaságokban, Közép-európai Közlemények, 5(12-13), 1965-200.

Magyar Nemzeti Bank (2018). Növekedési jelentés, MNB, Budapest, 160 p. ISSN-2416-3643

Pap, N. (2004). A kistérségek helye, szerepe Magyarországon a XXI. század első évtizedében. Tér és Társadalom 18(4), 24-41.

Pavlinek, P. (2004). Regional development implication of foreign direct investment in Central Europe, Sage Journal, 11, 47-70.

Pirisi, G. (2008). A magyar kisvárosok differenciált fejlődése a rendszerváltozás után. Doktori disszertáció. $151 \mathrm{p}$.

Pirisi, G., \& Sókuti, Z. (2013). Egy zsugorodó ipari kisváros - a gazdasági szerkezetváltás településszerkezeti hatásai Ajkán, Területfejlesztés és Innováció, 7, 2, 19-31.

Pirisi, G., \& Trócsányi, A. (2015). Bővülő állomány - zsugorodó elemek. A XXI. századi kisvárosi urbanizáció kétarcúsága Magyarországon. In Tésits, R. - Alpek, B. L. (Eds.). A mi geográfiánk. Tóth József emlékezete. Geographica Pannonica Nova 18. Publikon Kiadó, Pécs, 443-460.

Popescu, G. H. (2014). FDI and economic growth in Central and Eastern Europe. Sustainability, 6(11), 8149-8163.

Porter, M.E. (1996). Competitive Advantage, Agglomeration Economies, and Regional Policy. International Regional Science Review, 1-2, 85-94.

Tóth, J. (1996). A településrendszer. - In Perczel G. (Ed.) Magyarország társadalmi-gazdasági földrajza. ELTE Eötvös Kiadó, Budapest, 539-584.

Konecka-Szydlowska, B., Trócsányi, A., \& Pirisi, G. (2018): Urbanisation in a formal way? The different characteristics of the 'newest towns' in Poland and Hungary, Regional Statistics, 8, 2, 1-19.

Vápár, J. (2013). A német müködőtőke-befektetések Magyarországon. Tér és Társadalom, 1, $129-144$.

Wölfer, D. (2018). Konjunktúrajelentés, Deutsch-Ungarische Industrie- und Handelskammer, Budapest, $60 \mathrm{p}$.

Other sources from the internet:

OPTEN: - https://www.opten.hu/

CÉGINFORMÁCIÓ: - https://www.ceginformacio.hu/ 


\section{Appendices}

During the interviews with enterprises, we sought answers to the incentive factors of establishment, and the binding to minority presence

1. What kind of ownership structure does the company have?

2. Year of the company's foundation

3. Number of employees

4. How long has been working at this site/location?

5. Is it a newly created area or a brownfield investment?

6. Is your company affiliated with a franchise network?

7. Does your company function as a part of an international group of companies?

8. Which factors played significant a role in setting up your company?

\begin{tabular}{|l|lllc|}
\hline a) business-friendly local politics & 1 & 2 & 3 & 4 \\
\hline b) qualified workers & 1 & 2 & 3 & 4 \\
\hline $\begin{array}{l}\text { c) predictable economic } \\
\text { environment }\end{array}$ & 1 & 2 & 3 & 4 \\
\hline $\begin{array}{l}\text { d) friendly or informal working } \\
\text { environment }\end{array}$ & 1 & 2 & 3 & 4 \\
\hline e) developed of technical & 1 & 2 & 3 & 4 \\
\hline infrastructure & 1 & 2 & 3 & 4 \\
\hline g) sales markets & 1 & 2 & 3 & 4 \\
\hline h) adequate in size and good & 1 & 2 & 3 & 4 \\
\hline location & 1 & 2 & 3 \\
\hline
\end{tabular}

9. What qualifications do employees have (qualified, skilled worker, high school, university)?

10 . What is the average salary of the employees?

11 . What benefits do you receive in addition to your salary?

12. Do you consider it important to train your employees?

13. Does your supplier network work with domestic or foreign suppliers? What is the proportion of the domestic supplier?

14. Are you producing for the domestic or foreign sales market?

15. Has a strong national presence influenced the choice of location?

16. What are the short-term and long-term plans of the company? Do you plan to expand your capacity? Do you plan on technological development? Do you plan to move? Do you plan to expand your market? 